\title{
SOURCES OF ERROR IN THE ERYTHROCYTE SEDIMENTATION RATE
}

\author{
BY \\ J. S. LAWRENCE \\ From the Walkden Miners' Clinic and the Rheumatism Research Centre, University of Manchester
}

(RECEIVED FOR PUBLICATION JULY 16, 1953)

In recent papers on the plasma viscosity (Lawrence, $1949 ; 1950)$ it was suggested that the erythrocyte sedimentation rate, though a less accurate method of assessing the activity of disease than the fractional plasma viscosity, nevertheless gave important information, particularly when used in conjunction with the viscosity test. Moreover, the ease with which the sedimentation rate can be carried out commends it as a routine test. Unfortunately it is subject to many fallacies, some quite serious, and it is important that these should be fully understood if erroneous deductions are to be avoided. The extent of these fallacies can be judged when it is considered that, as noted in a recent paper (Lawrence, 1949) the erythrocyte sedimentation rate is found raised in less than half of the samples in which plasma protein changes of such a nature as to increase rouleaux formation and sedimentation have been demonstrated. The chief sources of error and those for which it is most difficult to correct are the erythrocyte-plasma ratio and erythrocyte size and composition, and these will therefore be considered first.

Erythrocyte Plasma Ratio.-This has already been investigated by a number of workers. In anaemia it may result in a disproportionately high figure for the sedimentation rate, and in polycythaemia in a normal erythrocyte sedimentation rate in the presence of active disease. In the past, much attention has been paid to the former effect, little to the latter. Studies in which the cell-plasma ratio has been adjusted in vitro (Westergren, 1924; Gram, 1928) show that reconstitution to a haemoglobin level above 130 per cent. of normal results in a normal erythrocyte sedimentation rate (less than $15 \mathrm{~mm}$.) in almost all pathological samples. With a haemoglobin of $\mathbf{4 0}$ per cent. or less, almost all sedimentation rates are raised whether the plasma is normal or pathological. Even an alteration of 10 per cent. in the haemoglobin value results in an increase or decrease of 20 to 50 per cent. in the erythrocyte sedimentation rate. In actual figures this may mean a variation of 10 to $72 \mathrm{~mm}$. Similar variations were noted when comparing the cell volume, instead of the haemoglobin concentration, with the erythrocyte $\mathrm{N}$ sedimentation rate.

\section{EXPERIMENTS}

(i) Anaemia and polycythaemia were produced in blood presenting originally no substantial abnormality of erythrocyte-plasma ratio (Table I, opposite). Such blood might be presumed to contain normal erythrocytes since it is in anaemia and polycythaemia that abnormal red cells are chiefly encountered.

Method.-Blood was collected in a graduated centrifuge tube containing an ammonium potassium oxalate mixt: (Heller and Paul, 1934). A sample was diluted with sese per cent. sodium citrate (one part of citrate to four partsoic blood) for the direct E.S.R. The remainder of the blo.oce was centrifuged for $30 \mathrm{~min}$. at 3,000 r.p.m. and the cell volume was measured. The plasma was then pipetted of and samples of plasma and packed cells in the requiredo proportions remixed; the mixture was then diluted witho sodium citrate as in the straight sample and the sedi- $\overrightarrow{\overrightarrow{0}}$ mentation carried out.

Results.-Samples A, B, and C, which are from healthy individuals, show cell volumes of 53-55 per cent $\stackrel{-}{-}$ In these, abnormal values for the E.S.R. were obtainedu only when the blood was reconstituted to a cell volume as low as 25 per cent. Of greater practical importance is the effect of raising the cell volume. An increase to 55 per. cent., for example, will result in a normal E.S.R. ino samples having a value as high as $39 \mathrm{~mm}$. at 45 per cent? cell volume. As a cell volume of 55 per cent. is withing normal limits, it follows that a false negative may readily arise even in the absence of an abnormal degree ofo polycythaemia.

(ii) The reverse process was studied, blood originally ${ }^{\circ}$ anaemic or polycythaemic being reconstituted to a normalN cell-plasma ratio (Table II, opposite).

For both these tests the blood was used undiluted as in Wintrobe's method. This results in a relativelye greater influence of the cell-plasma ratio on the E.S.R.D and would explain, for example, the much lower values? for the E.S.R. in those with high cell-plasma ratioso 
TABLE I

EFFECT OF ADJUSTMENT OF CELL-PLASMA RATIO ON THE ERYTHROCYTE SEDIMENTATION RATE (mm./hr) OF PATHOLOGICAL AND NORMAL SAMPLES OF BLOOD

\begin{tabular}{|c|c|c|c|c|c|c|}
\hline \multirow{3}{*}{ Sample } & \multirow{3}{*}{$\begin{array}{c}\text { Original } \\
\text { Cell } \\
\text { Volume (\%) }\end{array}$} & \multicolumn{5}{|c|}{ Erythrocyte Sedimentation Rate (mm./hr.) } \\
\hline & & \multirow{2}{*}{ Original } & \multicolumn{4}{|c|}{ With Reconstituted Cell Volume (\%) } \\
\hline & & & 25 & 35 & 45 & 55 \\
\hline $\begin{array}{l}\mathbf{A} \\
\mathbf{B} \\
\mathbf{C} \\
\mathbf{D} \\
\mathbf{E} \\
\mathbf{F} \\
\mathbf{G} \\
\mathbf{H} \\
\mathbf{I} \\
\mathbf{J} \\
\mathbf{K} \\
\mathbf{L} \\
\mathbf{M}\end{array}$ & $\begin{array}{l}55 \\
54 \\
53 \\
41 \\
48 \\
44 \\
39 \\
47 \\
50 \\
44 \\
46 \\
45 \\
45\end{array}$ & $\begin{array}{r}2 \\
2 \\
5 \\
73 \\
17 \\
39 \\
105 \\
33 \\
19 \\
52 \\
10 \\
29 \\
24\end{array}$ & $\begin{array}{r}16 \\
15 \\
16 \\
130 \\
132 \\
115 \\
127 \\
83 \\
132 \\
100 \\
83 \\
86\end{array}$ & $\begin{array}{r}7 \\
8 \\
8 \\
87 \\
83 \\
72 \\
109 \\
63 \\
46 \\
90 \\
28 \\
56 \\
44\end{array}$ & $\begin{array}{r}3 \\
5 \\
4 \\
61 \\
39 \\
38 \\
83 \\
27 \\
26 \\
55 \\
11 \\
28 \\
25\end{array}$ & $\begin{array}{r}1 \\
2 \\
1 \\
17 \\
6 \\
14 \\
39 \\
13 \\
19 \\
3 \\
6 \\
7\end{array}$ \\
\hline
\end{tabular}

in Table II, compared with those in Table I. The most striking features of Table II, however, are:

(1) the inconstancy of the effect of reconstitution,

(2) the comparatively low values for the E.S.R. in certain samples with quite marked anaemia (for example, Case 44, whose E.S.R. is only $3 \mathrm{~mm}$. despite a cell volume of only 27 per cent.).

The erythrocyte sedimentation rate changes in anaemia are therefore not simply those which would be expected on the basis of the erythrocyte-plasma ratio alone, and some other factor must be sought.

Effect of Cell Size and Composition.-This has been investigated by a number of workers. Newham and Martin (1928) found no correlation between red cell diameter and erythrocyte sedimentation rate in a number of infections. No allowance, however, was made for variations in cell volume or for the levels of fibrinogen and globulin in the plasma. Bendien, Neuberg, and Snapper (1932) overcame these difficulties by suspending cells of different colour index in samples of the same plasma at a constant cell volume. They found that the erythrocyte sedimentation rate was appreciably influenced by the type of erythrocyte, being diminished in the presence of a low colour index and raised when this was high. They suggested that cell density might be a determining factor. Ham and Curtis (1938) suspended, in the same plasma equal concentrations of micro-, normo-, and macrocytes. In this way they showed that the microcytes sedimented more slowly and macrocytes more rapidly than the normal cells. They concluded that cell size rather than density was the determining factor.

These observations are confirmed by data given in the Figure (overleaf), which shows the effect of cell size (mean cell volume) and haemoglobin content (mean cell haemoglobin or colour index) on the sedimentation rate. Samples of plasma from twenty
TABLE II

ERYTHROCYTE SEDIMENTATION RATE IN ANAEMIA AND POLYCYTHAEMIA

EFFECT OF RECONSTITUTION TO NORMAL CELL VOLUME

\begin{tabular}{|c|c|c|c|c|}
\hline $\begin{array}{l}\text { Case } \\
\text { No. }\end{array}$ & Diagnosis & $\begin{array}{c}\text { Cell } \\
\text { Volume } \\
(\%)\end{array}$ & $\begin{array}{c}\text { Simple } \\
\text { E.S.R. } \\
\underset{(\mathrm{mm} . /}{\mathrm{hr})}\end{array}$ & $\begin{array}{l}\text { Erythrocyte } \\
\text { Sedimenta- } \\
\text { tion Rate of } \\
\text { reconstituted } \\
\text { blood con- } \\
\text { taining } 45 \\
\text { per cent. of } \\
\text { patients' } \\
\text { cells (1 hr } \\
\text { readings) }\end{array}$ \\
\hline $\begin{array}{r}1 \\
2 \\
3 \\
4 \\
5 \\
6 \\
7 \\
8 \\
9 \\
10 \\
11 \\
12 \\
13 \\
14 \\
15 \\
16 \\
17 \\
18 \\
19 \\
20 \\
21 \\
22 \\
23 \\
24 \\
25 \\
26 \\
27 \\
28 \\
29 \\
30 \\
31 \\
32 \\
33 \\
34 \\
35 \\
36 \\
37 \\
38 \\
39 \\
40 \\
41 \\
42 \\
43 \\
44 \\
45 \\
47 \\
48 \\
49 \\
50 \\
51\end{array}$ & $\begin{array}{l}\text { Polycythaemia vera } \\
\text { Polycythaemia vera } \\
\text { Pulmonary tuberculosis } \\
\text { Pulmonary tuberculosis } \\
\text { Rheumatic heart } \\
\text { Pulmonary tuberculosis } \\
\text { Hysteria } . \\
\text { Gout } \quad . \\
\text { Gout } \\
\text { Primary atypical pneumoni } \\
\text { Chronic pneumonia } \\
\text { Gout } \\
\text { Rheumatoid arthritis } \\
\text { Chronic pneumonia } \\
\text { Gout } \\
\text { Pulmonary tuberculosis } \\
\text { Chronic pneumonia } \\
\text { Tuberculous pleurisy } \\
\text { Rheumatic heart . } \\
\text { Malaria } \\
\text { Rheumatoid arthritis } \\
\text { Thromboangitis obliteran } \\
\text { Rheumatoid arthritis } \\
\text { Tuberculous pleurisy } \\
\text { Rheumatoid arthritis } \\
\text { Rheumatoid arthritis } \\
\text { Hypochromic anaemia } \\
\text { Rheumatoid arthritis } \\
\text { Rheumatoid arthritis } \\
\text { Thromboangitis obliteran } \\
\text { Rheumatoid arthritis } \\
\text { Hypochromic anaemia } \\
\text { Carcinoma of pancreas } \\
\text { Thromboangiitis obliteran } \\
\text { Rheumatoid arthritis } \\
\text { Infective endocarditis } \\
\text { Rheumatoid arthritis } \\
\text { Bleeding jejunal ulcer } \\
\text { Rheumatoid arthritis } \\
\text { Hypochromic anaemia } \\
\text { Pernicious anaemia } \\
\text { Hypochromic anaemia } \\
\text { Hypochromic anaemia } \\
\text { Hypochromic anaemia } \\
\text { Hypochromic anaemia } \\
\text { Pernicious anaemia } \\
\text { Multiple myelomatosis } \\
\text { Hypochromic anaemia } \\
\text { Pernicious anaemia } \\
\text { Haemorrhagic gastritis } \\
\text { Tuberculous abscesses } \\
\text {. }\end{array}$ & 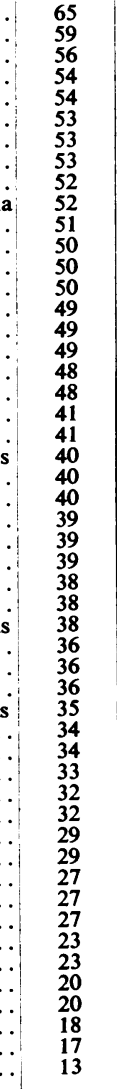 & $\begin{array}{r}0 \\
1 \\
7 \\
5 \\
2 \\
13 \\
1 \\
8 \\
9 \\
4 \\
4 \\
25 \\
7 \\
12 \\
12 \\
8 \\
6 \\
6 \\
13 \\
10 \\
19 \\
52 \\
49 \\
52 \\
102 \\
10 \\
13 \\
28 \\
21 \\
55 \\
44 \\
10 \\
93 \\
52 \\
30 \\
57 \\
95 \\
17 \\
123 \\
25 \\
53 \\
41 \\
40 \\
33 \\
33 \\
17 \\
122 \\
39 \\
49 \\
33 \\
80\end{array}$ & $\begin{array}{r}3 \\
3 \\
61 \\
49 \\
10 \\
25 \\
12 \\
66 \\
21 \\
22 \\
15 \\
45 \\
11 \\
38 \\
23 \\
45 \\
14 \\
13 \\
23 \\
44 \\
12 \\
38 \\
37 \\
37 \\
79 \\
4 \\
33 \\
14 \\
10 \\
39 \\
33 \\
6 \\
73 \\
31 \\
4 \\
40 \\
45 \\
1 \\
10 \\
10 \\
12 \\
7 \\
5 \\
1 \\
3 \\
3 \\
3 \\
3 \\
8 \\
6 \\
1 \\
34\end{array}$ \\
\hline
\end{tabular}

A 200-mm. column of blood was used in these tests. Normal values for oxalate blood, using a $200-\mathrm{mm}$. column, are up to $21 \mathrm{~mm}$. for males and $30 \mathrm{~mm}$. for females.

patients suffering from a number of maladies were each used to suspend several types of red cell of varying mean cell volume and haemoglobin. Each sample of plasma was tested with an average of three samples of cells and the figures on which the graphs are based are mean values for the twenty samples. The technique of reconstitution was identical with that used for the results in Table II. The cells were either of the same ABO group as the plasma or of group $\mathrm{O}$, a necessary precaution since agglutination interferes 


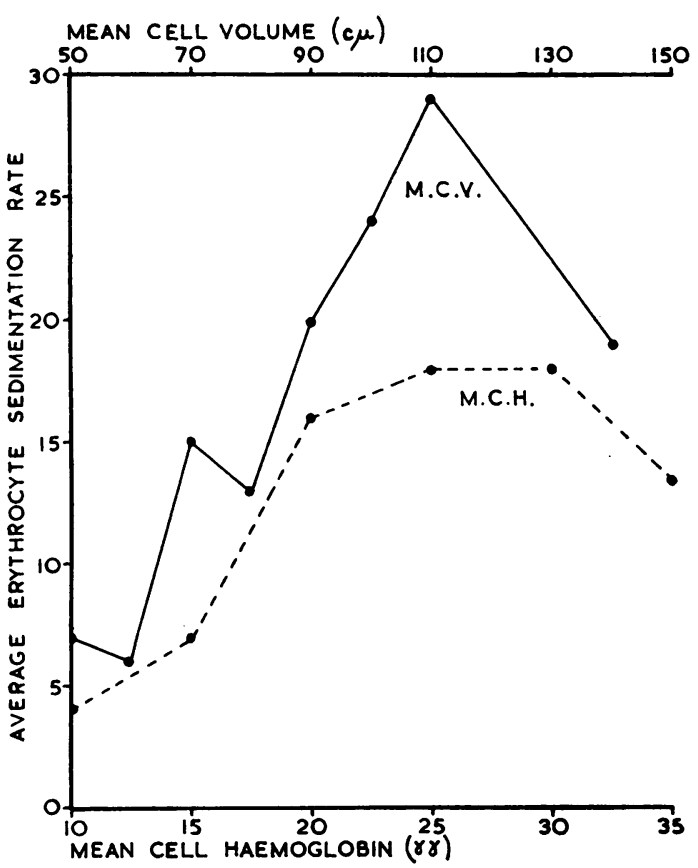

Figure.-Relationship of mean cell volume and mean cell hæmoglobin to et ythrocyte sedimentation rate.

with rouleaux-formation and so affects the sedimentation of erythrocytes. The proportion of cells in the mixture was 45 per cent. in each instance.

It is evident from these graphs that some relationship does exist between the sedimentation rate of cells and both their size and haemoglobin content. The very small cells (less than $70 \mathrm{c.} \mu$ ) always sedimented more slowly than normal cells and in some instances the difference was considerable. For example, in one instance, an erythrocyte sedimentation rate of $40 \mathrm{~mm}$. was reduced to $8 \mathrm{~mm}$. when microcytes were substituted for normal cells. Maximum sedimentation rates were, in general, found with cells of 110 to 130 c. $\mu$, the very large cells sedimenting less rapidly. A similar relationship existed with the haemoglobin content of the cells $\frac{C}{3}$ the maximum rate being obtained with cells of a colour index of 1.0 . Nevertheless, it was apparent? that neither the mean cell volume nor the haemo globin content is the sole erythrocyte factor capable? of modifying the erythrocyte sedimentation rate, fo? cells of closely similar properties were found to sediment at quite different rates.

A number of other cell factors have been inves尺 tigated (for example, the mean cell haemoglobił concentration, mean cell specific gravity, and mean cell weight, Table III), and it is apparent that no one of these factors is alone responsible for the varyin $\overrightarrow{\mathrm{s}_{\mathrm{N}}}$ influence of cells on the erythrocyte sedimentation rate. Of all factors studied, the mean cell specific gravity has the most constant relationship tơ erythrocyte modifications of the erythrocyte sedi $\omega_{0}$ mentation rate, and where there is a departure from this it is found that the mean cell volume shows conø siderable change. This is capable of explanation if if is assumed that the average number of cells perrouleaux is approximately constant for any giverf plasma. The rate of fall of the rouleaux, dependin as it does on their weight and size, would then be a combined factor of the mean cell values and the specific gravity of the cells: an increase of either the other remaining constant, would tend to incregse the rate of sedimentation. The rather lower rates obtained with very large cells may be due to intre ference with rouleaux formation by spheropoikilo-cytosis. Hardwicke and Squire (1952) havęํำ evolved a formula in which correction is made fof red cell and fluid specific gravity and fluid viscosity in blood reconstituted to a standard cell-plasma ratio $\overrightarrow{\vec{F}}$ in this way they obtained a close relationship between the plasma fibrinogen and the differencebetween the plasma and serum erythrocyte sedie mentation rate, but cells from idiopathic anaemia were not studied.

Rarely cells are encountered which do not sedioment appreciably in any plasma, however patho logical. This would be expected to occur whem

TABLE III

EFFECT OF CERTAIN ERYTHROCYTE CHARACTERISTICS ON SEDIMENTATION 45 PER CENT. OF FOUR DIFFERENT CELLS WITH ONE PLASMA

\begin{tabular}{|c|c|c|c|c|c|c|c|c|c|c|c|c|}
\hline $\begin{array}{l}\text { Red } \\
\text { Cells }\end{array}$ & +1 & Plasma & & $\begin{array}{l}\text { Erythrocyte } \\
\text { Sedimen- } \\
\text { tation Rate } \\
\text { (mm.) }\end{array}$ & $\begin{array}{c}\text { Mean } \\
\text { Cell } \\
\text { Volume }\end{array}$ & $\begin{array}{l}\text { Mean } \\
\text { Cell } \\
\text { Haemo- } \\
\text { globin }\end{array}$ & $\begin{array}{l}\text { Colour } \\
\text { Index }\end{array}$ & $\begin{array}{c}\text { Mean Cell Hb } \\
\text { Concentration } \\
(\%)\end{array}$ & $\begin{array}{c}\text { Cell } \\
\text { Specific } \\
\text { Gravity }\end{array}$ & $\begin{array}{c}\text { Mean } \\
\text { Cell } \\
\text { Weight }\end{array}$ & $\begin{array}{c}\text { Erythrocyte } \\
\text { Sedimentation } \\
\text { Rate of original } \\
\text { blood (mm.) }\end{array}$ & $\begin{array}{l}\text { Cell volume } \\
\text { of original } \\
\text { blood }(\%)\end{array}$ \\
\hline $\begin{array}{l}\mathbf{A} \\
\mathbf{B} \\
\mathbf{C} \\
\mathbf{D}\end{array}$ & $\begin{array}{l}+ \\
+ \\
+ \\
+\end{array}$ & $\begin{array}{l}\mathbf{A} \\
\mathbf{A} \\
\mathbf{A}\end{array}$ & $\begin{array}{l}= \\
= \\
= \\
=\end{array}$ & $\begin{array}{r}7 \\
12 \\
14 \\
21\end{array}$ & $\begin{array}{l}59 \\
83 \\
99 \\
75\end{array}$ & $\begin{array}{l}11 \\
21 \\
25 \\
17\end{array}$ & $\begin{array}{l}0.41 \\
0.75 \\
0.9 \\
0.61\end{array}$ & $\begin{array}{l}19 \\
25 \\
25 \\
23\end{array}$ & $\begin{array}{l}1 \cdot 106 \\
1 \cdot 100 \\
1 \cdot 126 \\
1 \cdot 144\end{array}$ & $\begin{array}{r}65 \\
91 \\
111 \\
86\end{array}$ & $\begin{array}{r}41 \\
39 \\
8 \\
15\end{array}$ & $\begin{array}{l}27 \\
38 \\
52 \\
33\end{array}$ \\
\hline $\begin{array}{l}\mathbf{E} \\
\mathbf{F} \\
\mathbf{G} \\
\mathbf{H}\end{array}$ & $\begin{array}{l}+ \\
+ \\
+ \\
+\end{array}$ & $\begin{array}{l}\mathbf{E} \\
\mathbf{E} \\
\mathbf{E} \\
\mathbf{E}\end{array}$ & $\begin{array}{l}= \\
= \\
= \\
=\end{array}$ & $\begin{array}{r}5 \\
5 \\
16 \\
24\end{array}$ & $\begin{array}{l}85 \\
66 \\
88 \\
94\end{array}$ & $\begin{array}{l}16 \\
13 \\
21 \\
27\end{array}$ & $\begin{array}{l}0.58 \\
0.47 \\
0.76 \\
0.85\end{array}$ & $\begin{array}{l}19 \\
19 \\
23 \\
25\end{array}$ & $\begin{array}{l}1 \cdot 082 \\
1 \cdot 110 \\
1 \cdot 112 \\
1 \cdot 128\end{array}$ & $\begin{array}{r}92 \\
73 \\
98 \\
106\end{array}$ & $\begin{array}{r}3 \\
4 \\
8 \\
14\end{array}$ & $\begin{array}{l}23 \\
27 \\
33 \\
43\end{array}$ \\
\hline
\end{tabular}


marked spherocytosis prevents rouleaux formation, it was encountered in two samples, one from a patient with polycythaemia vera, and the other from a patient with rheumatic carditis with mitral stenosis. The erythrocyte sedimentation rate, using these cells in plasma samples from blood with an erythrocyte sedimentation rate of 40 and $75 \mathrm{~mm}$. respectively, was 8 and $10 \mathrm{~mm}$. This property, however, is not usual in either of these conditions, and cells from such patients usually sediment normally when the cell volume is adjusted.

\section{SOURCES OF ERROR}

\section{Discussion}

(1) Cell Volume.--The data given above show that, using the blood sedimentation rate by standard methods, the chief source of error is the cell volume which is raised in a number of disease processes, particularly those affecting the heart and lungs. Quite a small increase of the cell volume is sufficient to reduce the erythrocyte sedimentation rate considerably; and a cell volume within the upper limit of normal may, despite appreciable changes in the fibrinogen and globulin fractions, be associated with a normal erythrocyte sedimentation rate. Errors in the reverse direction due to anaemia are less frequent. The erythrocyte sedimentation rate is also affected by changes in the mean cell volume and cell specific gravity, so that the erythrocyte sedimentation rate may not be raised in anaemia. This is particularly the case in hypochromic or microcytic anaemia, and simple correction of the cell volume by chart or by reconstitution with the patient's cells does not, therefore, always give a true value.

\section{(2) Red Cells}

(a) Effect of Drugs.-Certain drugs, when added to the plasma, reduce its ability to influence the sedimentation of red cells. Mercury compounds, for example, have this effect, and also sodium salicylate (Bendien and others, 1932). The fibrinogen content and plasma viscosity are unaltered, but the stability of the proteins as measured by Matefy's reaction is increased. This suggests that the hydration of the larger protein molecules is diminished, and a similar effect on the red cells may in some way effect their rouleaux-forming properties. In clinical practice, the concentration of sodium salicylate in the blood is generally not such as to affect the erythrocyte sedimentation rate. When, however, intensive treatment is used, it may produce a very significant retardation. In a patient with acute rheumatism receiving 20 gr. hourly, I have observed the erythrocyte sedimentation rate, which should have been in the 40 to $50 \mathrm{~mm}$. range as judged by the plasma fibrinogen level, to be only $4 \mathrm{~mm}$. When the dosage of salicylate was reduced the erythrocyte sedimentation rate rose to $55 \mathrm{~mm}$. without any appreciable alteration in the plasma fibrinogen level.

"Butazolidin" has also a considerable action on the erythrocyte sedimentation rate in vitro; for example, a concentration of $35 \mathrm{mg} . / 100 \mathrm{ml}$. will reduce the erythrocyte sedimentation rate from $23 \mathrm{~mm}$. to $2 \mathrm{~mm}$., and a single dose of $1 \mathrm{~g}$. administered to a patient with rheumatoid arthritis will temporarily reduce the erythrocyte sedimentation rate to about one-third of its previous value without affecting the plasma fibrinogen.

(b) Anaphylaxis.-An occasional source of error in the interpretation of erythrocyte sedimentation rate readings was noted by Caspari and others (1923) in patients suffering from scarlet fever under treatment with serum. Between the 11th and 13th day after the administration of serum, and synchronously with the appearance of cutaneous sensitivity to the serum (as shown by intradermal testing), there was a reduction of the erythrocyte sedimentation rate sometimes to normal. The reduction was only temporary and the erythrocyte sedimentation rate returned to its previous level in a day or two. This was sometimes, but not invariably, associated with symptoms and signs of serum sickness. Where serum had already been administered in a previous illness the phenomenon occurred earlier, usually 2 days after the serum injection. I have observed this phenomenon in a patient given antiscarlatinal serum for an attack of scarlet fever. After 9 days, despite an increase of the fibrinogen and $\gamma$-globulin consistent with an erythrocyte sedimentation rate of the order of $50 \mathrm{~mm}$., the erythrocyte sedimentation rate was only $2 \mathrm{~mm}$. The cell volume, though on the high side of normal, was insufficient to account for this low figure. By the 25 th day the erythrocyte sedimentation rate had risen to $88 \mathrm{~mm}$., a figure which corresponded with the plasma fibrinogen level. The mechanism of this phenomenon is not clear. The reaction between allergen and reagin may in some way interfere with the rouleaux-forming property of the red cells, possibly by producing spherocytosis.

(c) Bile Salts. - A high concentration of bile salts as in obstructive jaundice and hepatitis greatly retards the erythrocyte sedimentation rate (Noah and Hahn, 1928; Radosavljevic and Sekulic, 1932; Reichel, 1936).

Rarely, as already noted, there is no apparent cause for a failure of the red cells to sediment in pathological plasma. 
(3) Plasma Changes.-Where the viscosity of the plasma is very high, it may, in the absence of anaemia, retard the sedimentation of red cells (Lawrence, 1949). Where anaemia is present this effect is less obvious.

(4) Technical Factors.-The erythrocyte sedimentation rate is modified by such technical factors as the height, width, and inclination of the column of blood (Wintrobe and Landsberg, 1935; Reichel, 1936; Ham and Curtis, 1938), the anticoagulant used (Ham and Curtis, 1938), and the time allowed between collecting the blood and carrying out the test (Fahreus, 1921). Contamination of the blood by traces of spirit may also retard the erythrocyte sedimentation rate (Sykes, 1948). Seasonal variations of room temperature between summer and winter are sufficient to affect quite appreciably the sedimentation rate of blood, and in tropical climates the error may be considerable (Westergren, 1924). Todd (1946) observed that if the erythrocyte sedimentation rate is carried out at $37^{\circ} \mathrm{C}$. the $\frac{1}{2}-\mathrm{hr}$ reading is almost identical with the $1-\mathrm{hr}$ reading at $18^{\circ} \mathrm{C}$. My own observations have confirmed Todd's statement, particularly with regard to the critical range about the upper limit of normal. By carrying out the sedimentation rate at $37^{\circ} \mathrm{C}$. not only does a correction for room temperature become unnecessary, but errors due to cold agglutinins, which may occasionally cause very high erythrocyte sedimentation rate values in the absence of active disease, are completely avoided. As an incubator capable of containing an erythrocyte sedimentation rate rack is available in most laboratories no special apparatus is required, and this modification is therefore to be preferred for routine use. If, however, the test is carried out at room temperature the result should be corrected to a temperature of $18^{\circ} \mathrm{C}$. Data by which this may be done are given in Westergren's paper.

ChOICE of MethoD.-Of the standard methods, the Westergren test, despite its simplicity, is less liable to error than many of the more complicated procedures, the dilution and the retarding effect of the citrate anticoagulant tending to reduce errors due to abnormal cell-plasma ratios (Ham and Curtis, 1938). If it is carried out at $37^{\circ} \mathrm{C}$., errors due to temperature changes and to the presence of cold agglutinins are also avoided. Normal values at $30 \mathrm{~min}$. by this method are 2 to $9 \mathrm{~mm}$. in males and 3 to $15 \mathrm{~mm}$. in females.

More complicated procedures, involving for example the use of compatible red cells from a normal subject were used for a time by the author, but abandoned as being too complicated for routine use. It was found, moreover, that the fractionat plasma viscosity (Lawrence, 1950) gave more reliab information in less time. The method of Hardwick and Squire (1952), in which allowance is made fơ cell and plasma specific gravity and plasma viscosits also proved too complicated for clinical use. Theses authors also advise the viscosity method.

Methods using oxalate or heparin, in which correction is made for cell volume or haemoglobm concentration by means of a chart, are not advise $\$$ For the most part they reflect the changes in the plasma proteins less accurately than the simple Westergren method (Ham and Curtis, 1938). On the method of Rourke and Ernstene (1930) givess more reliable results, but the advantage is scarce such as to justify the greater complexity of the test. $\omega$

The Westergren erythrocyte sedimentation rates together with some rapid method of assaying fibrinogen and $\gamma$ globulin, such as the fractional plasma viscosity, is advised for assessment of the activity of disease processes for routine purposes.

\section{Summary}

The many fallacies associated with the erythrogy sedimentation rate as a measure of the plasing protein changes found in the presence of a ifice disease are discussed.

The factors responsible tend for the most part retard sedimentation and so to mask the presence $\overline{\text { of }}$ active disease, but a few have the opposite effect. $\frac{\circ}{\varnothing}$

It is important to use more direct methods of estimating plasma proteins, especially fibrinogen and $\gamma$ globulin. For this purpose the viscosity method recommended, and this may be combined with estimation of the sedimentation rate.

Where the erythrocyte sedimentation rate is use the Westergren method, carried out at $37^{\circ} \mathrm{C}$. over a period of 30 minutes, is advised for routine purposes.

\section{REFERENCES}

Bendien, W. M., Neuberg, J., and Snapper, I. (1932). Biochem. Z,

247, 306. Fahreus, R. (1921). Acta. med. scand., 55, 1.

Gram, H. C. (1928). Ibid., 68, 108.

Ham, T. H., and Curtis, F. C. (1938) Medicine, Baltimore, 17, 447 Hardwicke, J., and Squire, J. R. (1952). Clin. Sci., 11, 333.

Heller, V. G., and Paul, H. (1934). J. Lab. clin. Med., 19, 777

Lawrence, J.'S. (1949). Annals of the Rheumatic Diseases, 8, $209 . \mathrm{N}$ Lawrence, J. S. (1950). J. clin. Path. 3, 332. New (1950). J. clin. Path., 3, 332.

Newham, H. B., and Martin, P. H. (1928). Quart. J. Med., 22, 145. W Noah, G., and Hahn, E. (1928). Dtsch. med. Wschr., 54, 776.

Radosavljevic, A., and Sekulic, M. (1932). Progr. méd., Paris, 59, $17 \AA$ Reichel, H. (1936). "Blutkörperchensenkung". Springer, Vienna Rourke, M. D., and Ernstene, A. C. (1930). J. clin. Invest., 8, 545 .

Sykes, W. O. (1948). Brit. med. J., 1, 393.

Todd, G. S. (1946). Practitioner, 157, 36.

Westergren, A. (1924). Ergebn. inn. Med. Kinderheilk., 26, 577.

Wintrobe, M. M., and Landsberg, J. W. (1935). Amer. J. med. ScID 189,102 . 


\section{Causes d'erreur dans la vitesse de sédimentation globulaire}

\section{RÉSUMÉ}

On discute les nombreux erreurs concernant la vitesse de sédimentation globulaire en tant que mesure des altérations des protéines sanguines au cours d'une maladie active.

La plupart des facteurs responsables tendent à retarder la sédimentation et masquer ainsi la maladie, mais il y en a qui ont un effet contraire. Il est important qu'on emploie des méthodes plus directes pour déterminer les protéines du plasma, surtout le fibrinogène et la globuline. Pour cela on recommande la méthode basée sur la viscosité, à laquelle on peut associer la détermination de la vitesse de sédimentation.

Quand on détermine la vitesse de sédimentation globulaire pour des besoins ordinaires, il convient d'appliquer le procédé de Westergren à la température de $37^{\circ} \mathrm{C}$. pendant 30 minutes.

\section{Causas de error en la velocidad de sedimentaciôn eritrocitaria \\ SUMARIO}

Se discute las numerosas falacias asociadas con la velocidad de sedimentación eritrocitaria como medida de las alteraciones de las proteinas plasmáticas en presencia de una enfermedad activa.

La mayoría de los factores responsables tienden a retrasar la sedimentación disimulando así la presencia de una enfermedad activa, pero algunos tienen un efecto contrario. El empleo de métodos más directos para determinar las proteinas plasmáticas, en particular del fibrinógeno y de la globulina es, pués, importante. Con este objeto se recomenda el método de viscosidad, que se puede combinar con la determinación de la velocidad de sedimentación.

Al practicar la determinación de sedimentación eritrocitaria para usos ordinarios, se aconseja el método de Westergren a la temperatura de $37^{\circ} \mathrm{C}$. durante 30 minutos. 